\title{
Pengaruh Pinjaman yang Diberikan dan BOPO Pada Profitabilitas dengan Risiko Kredit sebagai Pemoderasi
}

\author{
I Gede Hendra Dharma Wicaksana ${ }^{1}$ \\ I Wayan Ramantha ${ }^{2}$
}

\author{
${ }^{1,2}$ Fakultas Ekonomi dan Bisnis Universitas Udayana (Unud), Bali, Indonesia
} e-mail: hendradharmawicaksana@gmail.com

\begin{abstract}
ABSTRAK
Pinjaman yang diberikan oleh bank dapat dikatakan efektif dan efisien apabila tidak terjadinya risiko kredit yaitu kredit macet. Penelitian ini bertujuan untuk menguji moderasi risiko kredit terhadap pinjaman yang diberikan dan BOPO pada profitabilitas bank. Profitabilitas dalam penilitian ini diukur dengan menggunakan ROA, dan pinjaman yang diberikan diukur dengan LDR, serta efisiensi diukur dengan BOPO. Penelitian ini merupakan penelitian kuantitatif berbentuk asosiatif. Populasi penelitian ini adalah perusahaan subsektor perbankan yang terdaftar di Bursa Efek Indonesia tahun 2013 s.d. 2017. Sampel ini diambil menggunakan teknik purposive sampling sehingga sampel yang diperoleh berjumlah 20 sampel perusahaan subsektor perbankan. Analisis data yang digunakan yaitu uji Moderated Regression Analysis (MRA). Berdasarkan hasil penelitian ini ditemukan bahwa risiko kredit memperlemah hubungan pinjaman yang diberikan pada profitabilitas dan memperkuat hubungan BOPO pada profitabilitas.
\end{abstract}

Kata Kunci: Pinjaman yang diberikan, NPL, BOPO

\section{ABSTRACT}

Loans provided by banks can be said to be effective and efficient if there is no credit risk, namely bad credit. This study aims to examine the moderation of credit risk to loans and $B O P O$ on the profitability of banks. Profitability in this research is measured using ROA, and loans given are measured by LDR, and efficiency is measured by BOPO. This research is an associative quantitative research. The population of this research is the banking subsector of companies listed on the Indonesia Stock Exchange in 2013 d. 2017. This sample was taken using a purposive sampling technique so that the samples obtained were 20 samples of the banking sub-sector companies. The data analysis used is the Moderated Regression Analysis (MRA) test. Based on the results of this study, it was found that credit risk weakened the lending relationship given to profitability and strengthened BOPO's relationship to profitability.

Keywords: Given loans, NPL, BOPO

\section{PENDAHULUAN}

Perbankan merupakan lembaga keuangan yang sangat penting peranannya dalam

kegiatan ekonomi, karena melalui kegiatan perkreditan dan jasa yang diberikan

oleh bank maka dapat melayani kebutuhan masyarakat dalam berbagai sektor 
ekonomi dan perdagangan. Pasal 1 UU No. 10 Tahun 1998 tentang perbankan menyatakan bahwa bank adalah badan usaha yang menghimpun dana dari masyarakat dalam bentuk simpanan dan menyalurkan dana kepada masyarakat dalam bentuk kredit dan atau bentuk-bentuk lainnya dalam rangka meningkatkan taraf hidup masyarakat banyak. Peranan bank sebagai lembaga keuangan baik dalam menghimpun dana masyarakat maupun menyalurkan kembali ke masyarakat semakin meningkat dalam kondisi perekonomian saat ini maupun dimasa yang akan datang, peranan perbankan mempunyai kedudukan yang strategis sebagai lembaga yang berfungsi memperlancar arus lalu lintas pembayaran dirasakan amat dibutuhkan (Iskandar, 2013:3).

Bank dalam melaksanakan kegiatan operasional mempunyai salah satu tujuan utama yaitu mencapai tingkat profitabilitas yang maksimal. Profitabilitas merupakan kemampuan sebuah perusahaan dalam menghasilkan laba pada periode tertentu (Riaz, 2014). Makna penting profitabilitas dapat juga digunakan dalam usaha mempertahankan kelangsungan hidup jangka panjang, karena untuk dapat menunjukkan suatu badan usaha yang memiliki prospek baik dapat diukur melalui profitabilitas (Haneef et al, 2012).

Menurut Derbali (2014) ketatnya peraturan bank dalam menyalurkan kredit akan meningkatkan profitabilitas. Rasio profitabilitas yang tinggi akan memberikan sinyal baik atau akan meningkatkan profitabilitas bank tersebut (Iloska, 2014). Return on Asset merupakan salah satu rasio profitabilitas. Dalam analisis laporan keuangan, rasio ini paling sering disoroti, karena mampu menunjukkan keberhasilan perusahaan menghasilkan keuntungan. ROA dapat 
mengukur kemampuan perusahaan menghasilkan keuntungan pada masa lampau untuk kemudian diproyeksi di masa yang akan datang. Asset atau aktiva yang dimaksud adalah keseluruhan harta perusahaan, yang diperoleh dari modal sendiri maupun modal asing yang telah diubah perusahaan menjadi aktiva-aktiva perusahaan yang digunakan untuk kelangsungan hidup perusahaan. ROA merupakan perbandingan antara tingkat kemampuan bank untuk menghasilkan keuntungan dibandingkan dengan jumlah total asset yang tersedia di bank (Dendawijaya, 2013). Semakin besar ROA maka menunjukkan semakin besar tingkat keuntungan yang dicapai oleh bank serta semakin baik pula kinerja bank dilihat dari sisi penggunaan asset yang dimilikinya.

Keuntungan bank sebagian besar berasal dari pendapatan bunga yang diperoleh dari aktivitas pemberian pinjaman. Pemberian pinjaman oleh bank dapat dilihat melalui Loan to Deposit Ratio (LDR). Rasio LDR merupakan perbandingan antara kredit yang diberikan dan dana pihak ketiga (Metasari, 2014). LDR dapat dijadikan sebagai indikator dalam melihat seberapa jauh fungsi dan efisiensi bank sebagai lembaga intermediasi dapat tercapai, serta digunakan untuk menilai tingkat kesehatan dan likuiditas suatu bank. Bank Indonesia menggunakan LDR sebagai salah satu indikator dalam menilai tingkat kesehatan terhadap bank-bank yang ada di Indonesia (Agustina dan Wijaya, 2013).

BOPO merupakan rasio perbandingan antara biaya operasional dengan pendapatan operasional. Semakin besar BOPO maka akan semakin kecil atau menurun kinerja keuangan perbankan. Begitu juga sebaliknya, jika BOPO semakin kecil, maka dapat disimpulkan bahwa kinerja keuangan perbankan 
semakin meningkat atau membaik. Rasio BOPO digunakan untuk mengukur tingkat efisiensi dan kemampuan bank dalam melakukan kegiatan operasinya (Dendawijaya, 2013). Biaya operasional merupakan biaya yang dikeluarkan oleh pihak bank dalam menjalankan aktivitasnya sehari-hari meliputi: biaya gaji, biaya pemasaran, biaya bunga. Sedangkan pendapatan operasional merupakan pendapatan yang diterima oleh pihak bank yang diperoleh melalui penyaluran kredit dalam bentuk suku bunga. Menurut SE BI Nomor 6/23/DPNP tanggal 31 Mei 2004 dan SE BI Nomor 13/24/DPNP tanggal 25 Oktober 2011 Bank Indonesia menetapkan besarnya rasio BOPO tidak melebihi 90 persen, bila melebihi 90 persen bank tersebut dikategorikan tidak efisien.

Penelitian tentang pengaruh kredit yang disalurkan pada profitabilitas sebelumnya sudah pernah dilakukan oleh Uremadu (2012) menunjukkan bahwa LDR berpengaruh positif terhadap ROA. Penelitian yang dilakukan oleh Negara \& Sujana (2014) juga menyatakan bahwa penyaluran kredit berpengaruh positif pada profitabilitas. Hasil tersebut sejalan dengan penelitian Septriani dan Ramantha (2014) menunjukkan kredit yang disalurkan berpengaruh positif pada profitabilitas. Penelitian yang dilakukan Prasanjaya dan Ramantha (2013) menyatakan bahwa BOPO berpengaruh positif pada profitabilitas. Namun, penelitian lain menunjukkan bahwa tidak selamanya LDR mempunyai pengaruh positif pada ROA. Penelitian Wibisono (2014) menyatakan bahwa LDR berpengaruh negatif pada ROA. Penelitian oleh Bwacha et al (2018) menunjukkan LDR berpengaruh negatif pada ROA. Penelitian mengenai hubungan antara BOPO dengan profitabilitas telah dilakukan oleh Aini (2013) 
yang menyatakan bahwa BOPO berpengaruh negatif pada profitabilitas. Hal tersebut didukung oleh penelitian yang dilakukan oleh Dewi dan Budiasih (2016) yang menyatakan bahwa BOPO berpengaruh negatif pada profitabilitas.

Beberapa hasil penelitian tersebut menunjukkan adanya ketidak konsistenan mengenai pengaruh pinjaman yang diberikan dan BOPO pada profitabilitas sehingga menimbulkan dugaan adanya variabel yang memoderasi hubungan diantara variabel tersebut. Variabel yang diduga memoderasi adalah risiko kredit. Menurut Sukma (2013) risiko kredit adalah risiko dari kemungkinan terjadinya kerugian bank sebagai akibat dari tidak dilunasinya kembali kredit yang diberikan bank kepada debitur. Menurut Gieseche (2004) risiko kredit adalah risiko yang paling signifikan yang dihadapi bank, dan keberhasilan bisnis mereka tergantung pada pengukuran yang akurat dan tingkat efisiensi yang lebih tinggi terhadap pengelolaan risiko ini dari pada risiko lainnya.

Risiko Kredit umumnya timbul dari berbagai kredit yang masuk dalam kategori bermasalah atau Non Performing Loan (NPL). Bank harus mampu meminimalkan rasio NPL karena rasio NPL berdampak pada profitabilitas bank tersebut. Tingginya NPL juga mengharuskan bank membentuk cadangan penghapusan piutang ragu-ragu sesuai dengan klasifikasi kredit bermasalah. Implementasi dari standar tersebut menyebabkan penurunan nilai buku dari pinjaman yang diberikan. Hal tersebut menjadi salah satu penghambat tersalurnya pinjaman yang diberikan oleh perbankan. NPL digunakan sebagai variabel pemoderasi karena diduga NPL yang tinggi akan berdampak pada kredit yang disalurkan sehingga profitabilitas bank akan menurun. 
Berikut pada Tabel 1 disajikan mengenai perkembangan ROA, LDR, BOPO, dan NPL pada bank-bank yang terdaftar di BEI pada tahun 2013 s.d. 2017

Tabel 1.

Perkembangan ROA, LDR, BOPO dan NPL pada Bank Umum Pada Tahun 2013 s.d. 2017

\begin{tabular}{|c|c|c|c|c|c|}
\hline \multirow{2}{*}{ Variabel } & \multicolumn{5}{|c|}{ Tahun } \\
\hline & 2013 & 2014 & 2015 & 2016 & 2017 \\
\hline ROA & 1,46 & 1,29 & 0,92 & 0,42 & 0,91 \\
\hline LDR & 86,46 & 82,93 & 84,75 & 84,04 & 82,49 \\
\hline BOPO & 86,83 & 87,59 & 91,24 & 97,02 & 92,06 \\
\hline NPL & 1,22 & 1,55 & 1,75 & 2,07 & 2,16 \\
\hline
\end{tabular}

Sumber: Data diolah, 2018

Berdasarkan Tabel di atas dapat dilihat bahwa rasio ROA mengalami penurunan dari tahun 2013 hingga tahun 2016 sebesar 0,62\% dan mengalami peningkatan tahun 2017. Rasio LDR mengalami naik turun pada periode 2013 s.d. 2017 namun masih dalam kondisi yang bagus karena rasio LDR tersebut telah memenuhi standar yang ditetapkan oleh Bank Indonesia yaitu berkisar antara $78 \%$ - 92\%. Rasio BOPO terus mengalami peningkatan dari tahun 2013 hingga pada tahun 2015 melebihi 90\% dimana ketentuan Bank Indonesia menyatakan jika BOPO melebihi 90\% maka bank dapat dikatakan tidak efisien.

Sedangkan rasio NPL terus mengalami peningkatan dari periode 2013 s.d. 2017 sebesar 0,93\%, ini menandakan kredit bermasalah yang dihadapi bank umum pada periode tersebut semakin banyak yang disebabkan oleh beberapa hal seperti sektor properti di Indonesia akhir-akhir ini mengalami perlambatan. Alhasil, hal ini memberikan pengaruh terhadap pengembalian dana debitur, selain itu perlambatan ekonomi domestik imbas dari perekonomian global dimana berdasarkan data Badan Pusat Statistik bahwa ekspor Indonesia dari tahun 2013 
hingga 2017 mengalami penurunan sebesar 7,5\%, lalu disebabkan juga oleh turunnya harga minyak mentah dan komoditas lainnya, serta pelarangan ekspor barang tambang menurut undang undang Nomor 4 Tahun 2009 tentang Pertambangan Mineral dan Batubara (Minerba) yang melarang ekspor produk minerba mentah mulai diberlakukan sejak 12 Januari 2014 membuat NPL perbankan terus meningkat. Kondisi ROA yang kurang baik menyebabkan profitabilitas bank menjadi semakin menurun dan peningkatan BOPO menunjukkan semakin menurun kinerja keuangan perbankan serta kenaikan NPL tersebut akan mengakibatkan bank menanggung biaya yang besar, jika tidak ada perbaikan maka akan mengurangi permodalan bank.

Atas dasar latar belakang tersebut, maka penelitian ini dimaksudkan untuk meneliti "Pengaruh Pinjaman yang Diberikan dan BOPO pada Profitabilitas Bank dengan Risiko Kredit sebagai Pemoderasi (Studi pada Industri Perbankan di Bursa Efek Indonesia pada tahun 2013 s.d. 2017)”. Pemilihan obyek penelitian pada sektor perbankan yang terdaftar di BEI dikarenakan perkembangan kinerja keuangan perbankan yang terdaftar di BEI dapat menjadi pilihan investasi yang baik dan menjanjikan bagi para calon investor untuk meningkatkan kesejahteraanya, sehingga perlu dilakukan analisis pada kinerja terutama dalam kemampuannya menghasilkan keuntungan.

Kegiatan penyaluran kredit yang dilakukan oleh perbankan mengandung risiko. Semakin besar kredit yang disalurkan oleh bank maka semakin besar pula risiko kredit yang akan dihadapi oleh bank tersebut. Risiko kredit merupakan risiko yang dihadapi bank karena menyalurkan dananya dalam bentuk pinjaman 
ke masayarakat. Risiko tersebut berupa tidak lancarnya pembayaran kredit atau kredit bermasalah yang dalam istilah perbankan dikenal dengan rasio Non Performing Loan (NPL). NPL merupakan besarnya jumlah kredit bermasalah pada suatu bank dibanding dengan total keseluruhan kreditnya (Negara dan Sujana, 2014). Timbulnya kredit bermasalah akan berakibat pada kerugian bank tersebut karena dana yang disalurkan oleh bank dalam bentuk kredit tersebut tidak kembali maupun pendapatan bunga yang tidak dapat diterima.

Penelitian mengenai pengaruh NPL pada kredit yang disalurkan yang diproksikan dengan LDR juga telah pernah dilakukan oleh Buchory (2014) yang menunjukkan bahwa NPL berpengaruh negatif pada LDR. Penelitian yang dilakukan oleh Zakaria (2015) juga menyatakan bahwa NPL berpengaruh negatif terhadap kredit yang disalurkan. Hal ini menandakan bahwa semakin besar NPL akan membuat lembaga keuangan perlahan mengurangi jumlah penyaluran kreditnya. Warsa dan Mustandha (2016) yang menyatakan bahwa NPL berpengaruh negatif pada ROA. Joseph et al (2012) memperoleh hasil bahwa NPL berpengaruh negatif terhadap ROA. Berdasarkan uraian tersebut, maka peneliti merumuskan hipotesis sebagai berikut.

$\mathrm{H}_{1}$ : Risiko Kredit memperlemah hubungan antara Pinjaman yang Diberikan pada Profitabilitas.

Bank apabila memiliki Non Performing Loan (NPL) yang tinggi, maka akan memperbesar biaya, baik biaya pencadangan aktiva produktif maupun biaya lainnya, dengan kata lain semakin tinggi NPL suatu bank, maka hal tersebut akan mengganggu kinerja bank tersebut (Ponco, 2008). Artinya, peningkatan kredit bermasalah dapat meningkatkan biaya yang dikeluarkan, sehingga dana yang 
awalnya dapat digunakan bank untuk memperoleh keuntungan menjadi berkurang, yang berdampak pada penurunan profitabilitas bank.

Pernyataan tersebut didukung oleh penelitian yang dilakukan oleh Setyawati dan Suartana (2014) menyatakan bahwa tingkat kredit bermasalah berpengaruh positif pada rasio BOPO. Berdasarkan uraian tersebut dapat dirumuskan hipotesis sebagai berikut:

$\mathrm{H}_{2}$ : Risiko kredit memperkuat pengaruh BOPO pada profitabilitas

\section{METODE PENELITIAN}

Penelitian ini dilakukan pada perusahaan subsektor perbankan yang terdaftar di Bursa Efek Indonesia pada periode 2013 s.d. 2017 dengan mengakses website resmi Bursa Efek Indonesia yaitu www.idx.co.id. Obyek yang menjadi kajian dalam penelitian ini adalah Pinjaman yang Diberikan, BOPO, Risiko Kredit dan Profitabilitas pada bank-bank yang terdaftar di Bursa Efek Indonesia periode 2013 s.d. 2017.

Rumus LDR adalah (Budiawati dan Jariah, 2012):

$$
\text { Rasio LDR }=\frac{\text { Kredit yang Diberikan }}{\text { Dana Pihak Ketiga }} \times 100 \%
$$

BOPO dihitung menggunakan rumus:

$$
\begin{aligned}
& \text { Rasio } \\
& \mathrm{BOPO}=\frac{\text { Total Beban Operasional }}{\text { Total Pendapatan Operasional }} \times 100 \%
\end{aligned}
$$

ROA dapat dihitung menggunakan rumus:

$$
\text { Rasio ROA }=\frac{\text { Laba Sebelum Pajak }}{\text { Rata-rata Total Aktiva }} \times 100 \%
$$


Rumus NPL adalalah (Metasari, 2014) :

$$
\text { Rasio NPL }=\frac{\text { Kredit Bermasalah }}{\text { Total Kredit }} \times 100 \%
$$

Populasi dalam penelitian ini adalah seluruh subsektor perbankan yang terdaftar di Bursa Efek Indonesia yaitu 41 subsektor perbankan. Sampel akan diambil dari populasi tersebut berdasarkan pendekatan non-probabilitas menggunakan teknik purposive sampling.

Pengujian hipotesis dilakukan dengan menggunakan analisis regresi moderasi atau Moderated Regression Analysis (MRA). . Model regresi moderasian penelitian ini ditunjukkan oleh persamaan berikut:

$Y=\alpha+\beta_{1} X 1+\beta_{2} X 2+\beta_{3} Z+\beta_{4}(X 1 * Z)+\beta_{4}(X 2 * Z)+e$

Keterangan:

$\begin{array}{ll}\mathrm{Y} & : \text { Profitabilitas } \\ \alpha & : \text { Konstanta } \\ \beta_{1}, \beta_{2}, \beta_{3} \beta_{4} \beta_{5} & : \text { Koefisien regresi } \\ \mathrm{X} 1 & : \text { Pinjaman yang diberikan } \\ \mathrm{X} 2 & : \text { BOPO } \\ \mathrm{Z} & : \text { Risiko Kredit } \\ \mathrm{e} & : \text { error }\end{array}$

\section{HASIL DAN PEMBAHASAN}

Statistik deskriptif disajikan untuk memberikan informasi mengenai karakteristik variabel-variabel penelitian, antara lain minimum, maksimum, mean, dan standar deviasi. Hasil dari statistik deskriptif dapat dilihat pada Tabel 2. 
Tabel 2.

Hasil Statistik Deskriptif

\begin{tabular}{lrrrrr}
\hline & $\mathrm{N}$ & \multicolumn{1}{c}{ Minimum } & \multicolumn{1}{c}{ Maximum } & \multicolumn{1}{c}{ Mean } & \multicolumn{1}{c}{ Std. Deviation } \\
\hline LDR & 100 & 45.72 & 113.30 & 84.9175 & 13.55631 \\
BOPO & 100 & 58.60 & 180.62 & 92.3435 & 20.45890 \\
NPL & 100 & .00 & 6.37 & 1.7238 & 1.22003 \\
ROA & 100 & -7.58 & 4.00 & .7451 & 2.14849 \\
X1.Z & 100 & .00 & 518.14 & 148.7716 & 105.46333 \\
X2.Z & 100 & .00 & 743.33 & 172.5165 & 151.11504 \\
Valid N (listwise) & 100 & & & & \\
\hline
\end{tabular}

Sumber: Data diolah, 2018

Berdasarkan hasil pengujian statistik deskriptif pada Tabel 1 jumlah sampel (N) dalam penelitian berjumlah 100. Nilai terendah dari data ditunjukkan oleh skor minimum, sedangkan nilai tertinggi dari data ditunjukkan oleh skor maksimum. Nilai mean dari variabel menunjukkan besarnya rata-rata penerapan variabel tersebut dan standar deviasi menunjukkan penyimpangan nilai variabel terhadap nilai rata-ratanya. Hasil analisis statistik deskriptif untuk masing-masing variabel dapat diuraikan dengan penjelasan sebagai berikut:

Tingkat pinjaman yang diberikan oleh bank-bank yang terdaftar di BEI yang diukur dengan Loan to Deposit (LDR) memiliki nilai minimum sebesar 45,72 dan nilai maksimum sebesar 113,30 . Nilai rata-rata LDR sebesar 84,91 ini menunjukkan bahwa nilai rata-rata LDR mendekati nilai maksimum dari pada nilai minimumnya. Hal ini menandakan pinjaman yang diberikan di Bank yang terdaftar di BEI baik. Standar deviasi LDR bank-bank yang terdaftar di BEI adalah 13,55 artinya terjadi penyimpangan nilai LDR terhadap nilai rata-ratanya sebesar 13,55 .

Tingkat Biaya Operasional dan Pendapatan Operasional pada bank-bank yang terdaftar di BEI memiliki nilai minimum sebesar 58,60 dan nilai maksimum sebesar 180,62. Nilai rata-rata BOPO sebesar 92,34 ini menunjukkan bahwa nilai 
rata-rata mendekati nilai minimum daripada nilai maksimumnya artinya tingkat efisiensi bank-bank yang terdaftar di BEI baik. Standar deviasi yang dimiliki BOPO sebesar 20,45, artinya terjadi penyimpangan nilai BOPO terhadap nilai rata-ratanya sebesar 20,45.

Tingkat risiko kredit yang diproksikan dengan NPL memiliki nilai minimum sebesar 0 dan nilai maksimum sebesar 6,37. Nilai rata-rata NPL sebesar 1,72 ini menunjukkan nilai rata-rata NPL mendekati nilai minimumnya dari pada nilai maksimumnya artinya risiko kredit yang dimiliki oleh Bank-bank yang terdaftar di BEI rendah. Standar deviasi yang dimiliki oleh NPL sebesar 1,22, artinya terjadi penyimpangan nilai NPL terhadap nilai rata-ratanya sebesar 1,22.

Tingkat profitabilitas yang diproksikan dengan ROA memiliki nilai minimum -7,58 dan nilai maksimum sebesar 4,00. Nilai rata-rata ROA adalah 0,74 ini menunjukkan nilai rata-rata ROA mendekati nilai maksimum dari pada nilai minimumnya artinya tingkat profitabilitas bank-bank yang terdaftar di BEI baik. Standar deviasi yang dimiliki oleh ROA sebesar 2,14 ini menunjukkan profitabilitas memiliki sebaran yang lebih besar karena standar deviasi lebih besar dari nilai rata-rata.

Untuk menguji apakah data yang digunakan normal atau tidak dapat dilakukan dengan menggunakan uji Kolmogorov Smirnov. Apabila koefisien Asymp. Sig. (2-tailed) lebih besar dari 0,05 maka data tersebut dikatakan berdistribusi normal 
Tabel 3.

Hasil Uji Normalitas

\begin{tabular}{llr}
\hline & & Unstandardized Residual \\
\hline $\mathrm{N}$ & & 100 \\
Normal Parameters ${ }^{\mathrm{a}, \mathrm{b}}$ & Mean & .0000000 \\
& Std. Deviation & .20809894 \\
Most Extreme Differences & Absolute & .126 \\
& Positive & .082 \\
& Negative & -.126 \\
Kolmogorov-Smirnov Z & & 1.258 \\
Asymp. Sig. (2-tailed) & & .084 \\
\hline Sumber: Data diolah, 2018 & &
\end{tabular}

Berdasarkan Tabel 3 dapat dilihat bahwa nilai Kolmogorov Smirnov (K-S) sebesar 1,258, sedangkan nilai Asymp. Sig. (2-tailed) sebesar 0,084. Hasil tersebut mengindikasikan bahwa model persamaan regresi tersebut berdistribusi normal karena nilai Asymp. Sig. (2-tailed) 0,084 lebih besar dari nilai alpha 0,05.

Suatu model regresi jika mengandung gejala autokorelasi, maka prediksi yang dilakukan dengan model tersebut akan tidak baik, atau dapat memberikan hasil prediksi yang menyimpang. Uji autokorelasi dalam peneitian ini dilakukan dengan Uji Durbin-Watson (DW-test) atau d statistik terhadap variabel pengganggu (disturbance error term).

Tabel 4.

Hasil Uji Autokorelasi

\begin{tabular}{lccccc}
\hline Model & & & Adjusted R & Std. Error of the \\
& $\mathrm{R}$ & R Square & Square & Estimate & Durbin-Watson \\
\hline 1 & $0,978^{\mathrm{a}}$ & 0,957 & 0,956 & 0,20994079 & 2,108 \\
\hline
\end{tabular}

Sumber: Data diolah, 2018

Nilai DW 2,108, nilai ini bila dibandingkan dengan nilai tabel signifikansi 5\%, jumlah sampel 100 (n) dan jumlah variabel independen $(K=3)$ maka diperoleh nilai du 1,7364. Nilai DW 2,108 lebih besar dari batas atas (du) yakni 1,7364 dan kurang dari (4-du) 4-1,7364 = 2,2636, maka dapat disimpulkan bahwa tidak terdapat autokorelasi. 
Untuk mendeteksi ada atau tidaknya korelasi antar variabel bebas dapat dilihat dari nilai tolerance dan nilai variance inflation factor (VIF). Jika nilai tolerance lebih dari $10 \%$ atau VIF Kurang dari 10, maka dapat dikatakan model telah bebas dari multikolinearitas.

Tabel 5.

Hasil Uji Multikoleniaritas

\begin{tabular}{cccc}
\hline Variabel & Tolerance & VIF & Keterangan \\
\hline LDR $\left(\mathrm{X}_{1}\right)$ & 0,964 & 1,038 & Bebas Multikolinieritas \\
BOPO $\left(\mathrm{X}_{2}\right)$ & 0,698 & 1,433 & Bebas Multikolinieritas \\
NPL $\left(\mathrm{X}_{3}\right)$ & 0,683 & 1,463 & Bebas Multikolinieritas \\
\hline
\end{tabular}

Sumber: Data diolah, 2018

Berdasarkan Tabel 5 dapat dilihat bahwa nilai tolerance dan VIF dari seluruh variable tersebut menunjukkan bahwa nilai tolerance untuk setiap variabel lebih besar dari $10 \%$ dan nilai VIF lebih kecil dari 10 yang berarti model persamaan regresi bebas dari multikolinearitas.

Jika tidak ada satu pun variabel bebas yang berpengaruh signifikan terhadap nilai absolute residual atau nilai signifikansinya di atas 0,05 maka tidak mengandung gejala heteroskedastisitas.

Tabel 6.

Hasil Uji Heteroskedastisitas

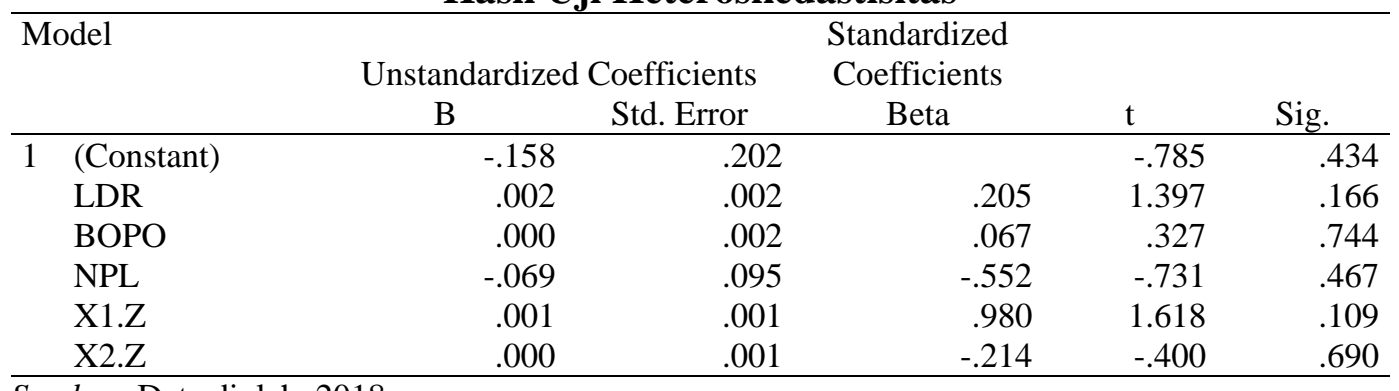

Sumber: Data diolah, 2018

Pada Tabel 6 dapat dilihat bahwa nilai Sig. dari variabel Pinjaman yang diberikan (LDR) sebesar 0,166, BOPO sebesar 0,744, risiko kredit (NPL) sebesar 0,467, variabel interaksi X1.Z sebesar 0,109 dan variabel interaksi X2.Z sebesar 
0,690. Nilai tersebut lebih besar dari 0,05 yang berarti tidak terdapat pengaruh antara variabel bebas terhadap absolute residual. Dengan demikian, model yang dibuat tidak mengandung gejala heteroskedastisitas.

Pengujian data dalam penelitian ini menggunakan teknik analisis regresi moderasi. Perhitungan koefisien regresi linier berganda dilakukan dengan analisis regresi melalui software SPSS 18.0 for Windows, diperoleh hasil yang ditunjukan pada Tabel 7 berikut :

Tabel 7.

Hasil Analisis Regresi Moderasi

\begin{tabular}{|c|c|c|c|c|c|c|}
\hline \multirow{2}{*}{\multicolumn{2}{|c|}{ Model }} & \multicolumn{2}{|c|}{$\begin{array}{l}\text { Unstandardized } \\
\text { Coefficients }\end{array}$} & \multirow{2}{*}{$\begin{array}{c}\begin{array}{c}\text { Standardized } \\
\text { Coefficients }\end{array} \\
\text { Beta } \\
\end{array}$} & \multirow[b]{2}{*}{$\mathrm{t}$} & \multirow[b]{2}{*}{ Sig. } \\
\hline & & B & Std. Error & & & \\
\hline \multirow[t]{6}{*}{1} & (Constant) & -.004 & .020 & & -.192 & .848 \\
\hline & LDR & .004 & .022 & .004 & .183 & .855 \\
\hline & BOPO & -.908 & .046 & -.908 & -19.863 & .000 \\
\hline & NPL & .334 & .100 & .334 & 3.332 & .001 \\
\hline & $\mathrm{X} 1 . \mathrm{Z}$ & -.071 & .034 & -.079 & -2.113 & .037 \\
\hline & $\mathrm{X} 2 . \mathrm{Z}$ & -.309 & .119 & -.309 & -2.597 & .011 \\
\hline \multicolumn{4}{|c|}{ R Square } & & & 0,962 \\
\hline \multicolumn{4}{|c|}{ Adjusted R Square } & & & 0,960 \\
\hline \multicolumn{4}{|c|}{ F Statistik } & & & 475,101 \\
\hline \multicolumn{4}{|c|}{ Signifikansi } & & & 0,000 \\
\hline
\end{tabular}

Berdasarkan hasil analisis regresi moderasi seperti yang disajikan pada Tabel 7, maka persamaan strukturalnya adalah sebagai berikut :

$$
Y=-0,004+0,004 X_{1}-0,908 X_{2}+0,334 Z-0,071 X_{1} * Z-0,309 X_{2} * Z+
$$

Koefisien determinasi $\left(\mathrm{R}^{2}\right)$ bertujuan untuk mengetahui dan mengukur kemampuan model dalam menerangkan variasi variabel independen digunakan. Peneliti menggunakan nilai adjusted $\mathrm{R}^{2}$ pada saat mengevaluasi yang mana model regresi terbaik, karena tidak seperti $\mathrm{R}^{2}$, nilai adjusted $\mathrm{R}^{2}$ dapat naik atau turun apabila satu variabel independen ditambahkan ke dalam model. Hasil uji memberikan hasil dimana diperoleh besarnya adjusted $\mathrm{R}^{2}$ (koefisien determinasi 
yang telah disesuaikan) pada Tabel 7 adalah 0,960. Ini berarti variasi profitabilitas di Perusahaan subsektor perbankan yang terdaftar di Bursa Efek Indonesia pada periode 2013 s.d. 2017 dapat dipengaruhi secara signifikan oleh variabel Pinjaman yang diberikan $\left(\mathrm{X}_{1}\right)$, BOPO $\left(\mathrm{X}_{2}\right)$, risiko kredit $(\mathrm{Z})$, variabel interaksi $\mathrm{X} 1 . \mathrm{Z}$ dan variabel interaksi X2.Z sebesar $96 \%$ sedangkan sisanya sebesar $4 \%$ dijelaskan oleh faktor-faktor lain.

Uji keterandalan model atau uji kelayakan model atau yang lebih populer disebut sebagai uji $\mathrm{F}$ merupakan tahapan awal mengidentifikasi model regresi yang diestimasi layak atau tidak. Layak (andal) disini maksudnya adalah model yang diestimasi layak digunakan untuk menjelaskan pengaruh variabel-variabel bebas terhadap variabel terikat. Sig. Tabel ANOVA menunjukkan besarnya angka probabilitas atau signifikansi pada perhitungan ANOVA. Nilai yang tertera digunakan untuk uji kelayanan Model Analisis (dimana sejumlah variabel $\mathrm{x}$ mempengaruhi variabel y) dengan ketentuan angka probabilitas yang baik untuk digunakan sebagai model regresi harus $<0,05$. Nilai ini bisa dilihat pada kolom Sig. Jika signifikansi $<0,05$, maka Model Analisis dianggap layak. Jika nilai signifikansi > 0,05, maka Model Analisis dianggap tidak layak.

Tabel 8.

\section{Uji ANOVA}

\begin{tabular}{llrrrrr}
\hline Model & & Sum of Squares & df & Mean Square & F & Sig. \\
\hline 1 & Regression & 95.232 & 5 & 19.046 & 475.101 & $.000^{\mathrm{a}}$ \\
& Residual & 3.768 & 94 & .040 & & \\
& Total & 99.000 & 99 & & & \\
\hline
\end{tabular}

Sumber : Data diolah, 2018

Hasil uji F (Ftest) menunjukkan bahwa nilai signifikansi P value 0,000 yang lebih kecil dari $\alpha=0,05$, ini berarti model yang digunakan pada penelitian ini adalah layak. Hasil ini memberikan makna bahwa seluruh variabel independen 
yaitu Pinjaman yang diberikan $\left(\mathrm{X}_{1}\right)$, BOPO $\left(\mathrm{X}_{2}\right)$, risiko kredit $(\mathrm{Z})$, variabel interaksi antara pinjaman yang diberikan dengan risiko kredit (X1.Z) dan variabel interaksi antara BOPO dengan risiko kredit (X1.Z) mampu memprediksi atau menjelaskan fenomena profitabilitas. Hal ini berarti model dapat digunakan untuk analisa lebih lanjut atau dengan kata lain model dapat digunakan untuk memproyeksikan karena hasil goodness of fitnya baik dengan nilai signifikansi $\mathrm{P}$ value 0,000 .

Kriteria pengujian untuk menjelaskan interpretasi pengaruh antar masingmasing variabel yakni jika nilai signifikansi $<0,05$ maka $\mathrm{H}_{0}$ ditolak dan $\mathrm{H}_{1}$ diterima. Sebaliknya, jika nilai signifikansi > 0,05 maka $\mathrm{H}_{0}$ diterima dan $\mathrm{H}_{1}$ ditolak. Variabel moderasi dapat diklasifikasikan menjadi 4 jenis. Masing-masing klasifikasi moderasi dapat diidentifikasi sebagaimana contoh berikut, jika $\mathrm{X}$ adalah variabel predictor, $\mathrm{Y}$ variabel terikat dan $\mathrm{Z}$ variabel moderasi maka persamaan regresi yang dapat dibentuk sebagai berikut :

$$
Y=\beta_{1} X_{1}+\beta_{2} X_{2}+\beta_{3} Z_{1}+\beta_{4} X_{1} * Z+\beta_{5} X_{2} * Z
$$

Berdasarkan hasil penelitian, risiko kredit mampu memoderasi dengan memperlemah pengaruh pinjaman yang diberikan pada profitabilitas. Oleh karena itu hipotesis yang diajukan dalam penelitian ini yaitu risiko kredit memperlemah pengaruh pinjaman yang diberikan pada profitabilitas diterima. Hipotesis ini diterima karena setiap pinjaman yang diberikan oleh bank kepada nasabah selalu mengandung risiko. Semakin besar jumlah pinjaman yang diberikan oleh bank maka semakin besar pula risiko pinjaman yang diberikan yang akan dihadapi oleh bank tersebut. Risiko tersebut berupa tidak lancarnya pembayaran pinjaman yang 
diberikan atau kredit bermasalah yang dalam istilah perbankan dikenal dengan rasio NPL.

Tabel 9.

Klasifikasi Variabel Moderasi

\begin{tabular}{cll}
\hline No. & \multicolumn{1}{c}{ Tipe Moderasi } & \multicolumn{1}{c}{ Koefisien } \\
\hline 1. & Pure Moderasi & $\mathrm{b}_{3}$ non significant \\
2. & Quasi Moderasi & $\mathrm{b}_{4}, \mathrm{~b}_{5}$ significant \\
& & $\mathrm{b}_{3}$ significant \\
3. & Homologiser Moderasi & $\mathrm{b}_{4}, \mathrm{~b}_{5}$ significant \\
4. & Predictor Moderasi & $\mathrm{b}_{3}$ non significant \\
& & $\mathrm{b}_{4}, \mathrm{~b}_{5}$ non significant \\
\hline
\end{tabular}

Sumber: Data diolah, 2018

Timbulnya kredit bermasalah akan berakibat pada kerugian bank tersebut karena pinjaman yang diberikan oleh bank dalam bentuk kredit tersebut tidak kembali maupun pendapatan bunga yang tidak dapat diterima sehingga akan menyebabkan profitabilitas menurun. Standar akuntansi perbankan mengharuskan bank membentuk cadangan penghapusan piutang ragu-ragu sesuai dengan klasifikasi kredit bermasalah. Implementasi dari standar tersebut menyebabkan penurunan nilai buku dari pinjaman yang diberikan.

Hasil penelitian ini sejalan dengan penelitian Buchory (2014) menyatakan bahwa NPL memperlemah kredit yang disalurkan pada profitabilitas. Utami dan Putra (2016) juga menyatakan bahwa NPL memperlemah pengaruh pinjaman yang diberikan pada profitabilitas.

Berdasarkan hasil penelitian, risiko kredit mampu memoderasi dengan memperkuat pengaruh BOPO pada profitabilitas. Oleh karena itu hipotesis yang diajukan dalam penelitian ini yaitu risiko kredit memperkuat pengaruh BOPO pada profitabilitas diterima. Bank apabila memiliki Non Performing Loan (NPL) 
yang tinggi, makan akan memperbesar biaya, baik biaya pencadangan aktiva produktif maupun biaya lainnya, dengan kata lain semakin tinggi NPL suatu bank, maka hal tersebut akan mengganggu kinerja bank tersebut (Ponco, 2008). Artinya, peningkatan kredit bermasalah dapat meningkatkan biaya yang dikeluarkan, sehingga dana yang awalnya dapat digunakan bank untuk memperoleh keuntungan menjadi berkurang, yang berdampak pada penurunan profitabilitas bank.

Pernyataan tersebut didukung oleh penelitian yang dilakukan oleh Setyawati dan Suartana (2014) menyatakan bahwa tingkat kredit bermasalah berpengaruh positif pada rasio BOPO. Penelitian yang dilakukan oleh Dewi (2016) menyatakan bahwa NPL memperkuat pengaruh BOPO pada profitabilitas.

Penelitian ini menghasilkan kesimpulan mengenai NPL memperlemah pinjaman yang diberikan pada profitabilitas dan memperkuat BOPO pada profitabilitas bank. Untuk itu, sebelum realisasi kredit dilaksanakan, pengelola bank harus serius dalam seleksi dan mengestimasikan kelancaran pengembalian kredit agar pinjaman yang diberikan dapat dikatakan efektif dan efisien sehingga mengurangi NPL bank. Di samping itu pihak kreditur juga harus dapat memberikan timbal balik atas kepercayaan dalam memberikan pinjaman oleh pihak bank dengan mengembalikan dana yang diberikan. Hasil penelitian ini berhasil membuktikan bahwa berdasarkan teori stewardship dalam penelitian ini dapat menjelaskan bahwa manajemen (steward) dalam mengelola bank akan mengesampingkan kepentingan pribadi mereka dan memaksimalkan kinerjanya untuk mencapai tujuan. Begitupula sebaliknya, dalam hal pemberian kredit, 
nasabah sebagai steward yang telah diberikan kepercayaan oleh pihak bank (principal) untuk mengelola sebagian dana bank akan berusaha semaksimal mungkin untuk mengembalikan dana yang diberikan.

Penelitian ini diharapkan dapat memberikan kontribusi positif bagi semua pihak khususnya pihak investor dan perbankan. Bagi pihak perbankan diharapkan untuk lebih selektif dalam memberikan kredit kepada calon kreditur agar meminimalisisr terjadinya kredit macet. Kredit macet yang terjadi dapat mengurangi laba sehingga bank akan terlihat tidak sehat. Bagi para calon investor untuk dapat menganalisis kinerja bank terutama dalam kemampuannya menghasilkan keuntungan sehingga dapat meningkatkan kesejahteraan para calon investor.

\section{SIMPULAN}

Risiko kredit memperlemah pengaruh pinjaman yang diberikan pada profitabilitas bank-bank yang terdaftar di Bursa Efek Indonesia periode 2013 s.d. 2017. Risiko kredit memperkuat pengaruh BOPO pada profitabilitas bank-bank yang terdaftar di Bursa Efek Indonesia periode 2013 s.d. 2017.

Berdasarkan hasil penelitian yang menyatakan bahwa risiko kredit memperlemah pengaruh pinjaman yang diberikan pada profitabilitas dan memperkuat pengaruh BOPO pada profitabilitas bank karena pihak ketiga yang tidak bisa melunasi kewajibannya, jadi sebaiknya sebelum memberikan pinjaman kepada calon nasabah, sebaiknya terlebih dahulu menganalisis calon nasabah dengan menerapkan prinsip $5 \mathrm{C}$ dan $7 \mathrm{P}$ sehingga meminimalisir timbulnya kredit 
macet kedepannya. Penyaluran kredit yang efektif dan efisien akan meminimalisir timbulnya NPL sehingga profitabilitas bank akan meningkat.

Bagi peneliti yang ingin melakukan penelitian sejenis sebaiknya menggunakan variabel-variabel bebas lain yang mampu mempengaruhi profitabilitas seperti tingkat kecukupan modal dan suku bunga atau menggunakan variabel moderasi lain seperti dana pihak ketiga.

\section{REFERENSI}

Agustina, \& Wijaya, A. (2013). Analisis faktor-faktor yang mempengaruhi loan to deposit ratio bank swasta nasional di Bank Indonesia. Jurnal Wira Ekonomi Mikroskil, 3(2), 101-109.

Aini, N. (2013). Pengaruh CAR, NIM, LDR, NPL, BOPO, dan Kualitas Aktiva Produktif Terhadap Perubahan Laba. Dinamika Keuangan, Akuntansi Dan Perbankan, 2(1), 14-25. Retrieved http://portalgaruda.org/?ref=browse\&mod=viewarticle \&article=141415

Alper, D. and A. A. (2011). Bank Specific And Macroeconomic Determinants of Commercial Bank Profitability: Emprical Evidence from Turkey. Journal Business and Economics, Vol.2 Numb, pp: 139-152.

Ariyanto, T., \& Indonesia, B. (2011). Vol13_No1_Juni2011.

Baridwan Zaki. (2004). Intermediate Accounting (Kedelapan). Yogyakarta: BPFE-Yogyakarta.

Brigham Eugene F dan Houston Joel F. (2010). Dasar-dasar Manajemen Keuangan (11th ed.). Jakarta: Salemba Empat.

Buchory Herry Achmad. (2014). Analysis of the Effect of Capital, Net Interest Margin, Credit Risk and Profitability in the Implementation of Banking Intermediation (Study On Regional Development Bank All Over Indonesia In 2012 ). European Journal of Business and Management, 6(4), pp: 20-32.

Budiawati, H., \& Jariah, A. (2012). Analisis Non Performing Assets Dan Loan To Deposits Ratio Serta Pengaruhnya Terhadap Net Interest Margin Sebagai Indikator Spread Based Pada Bank Umum Swasta Nasional Di Indonesia Periode 2004 - 2007. Jurnal WIGA, 2(2), 90-102. 
Bwacha, C. R., \& Xi, J. (2018). The Impact of Liquidity on Profitability : An explanatory study of the banking sector between 2008 and 2017.

Dendawijaya. (2013). Manajemen Perbankan. (Cetakan. Kedua, Ed.) (Edisi Kedu). BogorJakarta: Ghalia Indonesia.

Derbali, A. (2014). The impact of banking strategies on the net interest margin: Empirical evidence from Tunisia. International Journal of Innovation and Applied Studies, 6 (1), pp:

Dewi, N. P. E. N., \& I Gusti Ayu Nyoman Budiasih. (2016). Kualitas Kredit Sebagai Pemoderasi Pengaruh Tingkat Penyaluran Kredit dan BOPO pada Profitabilitas. E-Jurnal Akuntansi, 784-798.

Dietrich, A., \& Wanzenried, G. (2011). Determinants of bank profitability before and during the crisis: Evidence from Switzerland. Journal of International Financial Markets, Institutions and Money, 21(3), 307-327. https://doi.org/10.1016/j.intfin.2010.11.002

Faud, R., \& D.M, M. R. (2005). Akuntansi Perbankan petunjuk praktis operasional bank. Surabaya: Graha Ilmu.

Ghozali, I. (2016). Aplikasi Analisis Multivariet Dengan Program SPSS (8th ed.). Badan Penerbit Universitas Diponegoro.

Gieseche, K. (2004). Credit risk modelling and valuation: An introduction, Credit Risk. Models and Management. Cornell University, London, Vol. 2.

H.David, J., Schoorman, F. D., \& Donaldson, L. (1997). Copyright (C) 1997. All rights reserved. International Journal of Plant Science, 158, S65-S80. https://doi.org/10.2307/259249

Haneef Shahbaz, Riaz Tabassum, Ramzan Muhammad, Rana Mansoor Ali, I. H. M. and K. Y. (2012). Impact of Risk Management on Non-Performing Loans and Profitability of Banking Sector of Pakistan. International Journal of Business and Social Science, 3 (7),

Harahap, S. S. (2010). Analisis Krisis atas Laporan Keuangan. Jakarta: PT Raja Grafindo Persada.

Hidayat, T., Hamidah, \& Mardiyati, U. (2012). Analisis Pengaruh Karakteristik Bank Dan Inflasi Terhadap Net Interest Margin Studi Kasus Pada Bank Konvensional yang Terdaftar di Bursa Efek Indonesia Tahun 2006-2010. Analisis Pengaruh Karakteristik Bank Dan Inflasi Terhadap Net Interest Margin Studi Kasus Pada Bank Konvensional Yang Terdaftar Di Bursa Efek Indonesia Tahun 2006-2010, 3(1), 1-15. 
IAI. (2017). Standar Akuntansi Keuangan.

Iloska, N. (2014). Determinants Of Net Interest Margins - The Case Of Macedonia. Journal of Applied Economics and Business, 2 (2),

Ismail. (2010). Akuntansi Bank. Jakarta: Kencana.

Joseph Mabvure Tendai, Edson Gwangwava, Manuere Faitira, C. M. and M. K. (2012). Non Performing loans in Commercial Banks: A case of CBZ Bank Limited In Zimbabwe. Interdisciplinary Journal of Contemporary Research In Business, 4(7), pp:467-488.

Kasmir. (2012). Analisis Laporan Keuangan. Jakarta: PT Raja Grafindo Persada.

Lie, L. (2009). Penggunaan MRA dengan Spss untuk Menguji Pengaruh Moderating terhadap Hubungan antara Variabel Independen dan Variabel Dependen. Jurnal Teknologi Informasi Dinamik, 14(2), pp:90-97.

Manurung, Mandala; Rahardja, P. (2004). Teori Ekonomi Makro Suatu Pengantar. Jakarta: Fakultas Ekonomi Indonesia.

Metasari, D. R. (2014). Pengaruh Capital Adequacy Ratio, Non Performing Loan, Loan to Deposit Ratio, Net Interest margin, dan BOPO pada Tingkat Profitabilitas Bank (Studi pada Bank Umum yang Terdaftar di Bursa Efek Indonesia). E-Jurnal Akuntansi Universitas Brawijaya.

Murhadi Werner R. (2013). Analisis Laporan Keuangan Proyeksi dan Valuta Asing. Jakarta: Salemba Empat.

Negara, I. putu A. N., \& Sujana, I. ketut. (2014). Pengaruh Capital Adequacy Ratio, Penyaluran Kredit dan Non Performing Loan pada Profitabilitas. EJurnal Akuntansi Universitas Udaya ISSN: 2302-8556, 2, 325-339. https://doi.org/10.4315/0362-028X-61.8.1023

Ponco, B. (2008). Analisis Pengaruh CAR, NPL, BOPO, NIM dan LDR terhadap ROA (Studi Kasus Pada Perusahaan Perbankan yang Terdaftar di Bursa Efek Indonesia Periode 2004-2007. Diss. Program Pascasarjana Universitas Diponegoro.

Prasanjaya, A. A. Y., \& Ramantha, I. W. (2013). Analisis Pengaruh Rasio CAR, BOPO, LDR, dan Ukuran Perusahaan Terhadap Profitabilitas Bank yang Terdaftar Di BEI. E-Jurnal Akuntansi Universitas Udayana, 4(1), 230-245. https://doi.org/10.1016/j.jemermed.2010.11.035

Riyadi Slamet, \& Agung., Y. (2014). Pengaruh Pembiayaan bagi Hasil, Pembiayaan Jual Beli, Financing to Deposit Ratio (FDR) dan Non 
Performing Financing (NPF) terhadap Profitabilitas Bank Umum Syariah di Indonesia. Accounting Analysis Journal, 3.4.

Rmp, M., \& Ni, M. (2014). Faktor-faktor yang Mempengaruhi Net Interest Margin ( Bank Go Publik Tahun 2008 s/d 2011) Peringkat Bank-Bank Persero BUSN Devisa BUSN Non Devisa BPD Bank Campuran Bank Asing Bank Umum Tahun Rata-rata, VI(6), 69-80.

Saba, I., Kouser, R., \& Azeem, M. (2012). Determinants of Non Performing Loans: Case of US Banking Sector. The Romanian Economic Journal, (January), 141-152.

Saeed, M. S. (2014). Using Loan-to-Deposit Ratio to Avert Liquidity Risk: A Case of 2008 Liquidity Crisis, 5(3), 75-80.

Said, R. M. and M. H. T. (2011). Performance and Financial Ratios of Commercial Banks in Malaysia and China. International Review of Business Research Papers, Vol.7, No., 157-169.

Septriani, N. L. S., \& Wayan, R. I. (2014). Pengararuh rasio kecukupan modal dan rasio penyaluran kredit terhadap profitabilitas dengan moderasi rasio kredit bermasalah. E-Jurnal Akuntansi Universitas Udayana, 7(1), 192-206.

Setyawati, A. A. P., \& I Wayan Suartana. (2014). Pengaruh Pertumbuhan Aktiva Produktif, Dana Pihak Ketiga, Tingkat Kredit Bermasalah dan Ukuran LPD Pada Kinerja Operasional. E-Jurnal Akuntansi, 598-608.

Siamat, D. (2004). Manajemen Lembaga Keuangan. Jakarta: LPFE-UI.

Simanjuntak, T. B. (2016). Analisis Pengaruh Faktor Makro dan Mikro Ekonomi Terhadap Return Saham Sektor Perbankan di Bersa Efek Indonesia Tahun 2010-2014. Jurnal Ilmiah Mahasiswa FEB, 5.1.

Siswanto, S. (1995). Analisa Kredit Bank Umum.Jakarta. Pustaka Binaman Pressindo.

Sugiyono. (2013). Metode Penelitian Bisnis (Pendekatan Kuantitatif, Kualitatif, dan $R \& D)$. (C. Alfabeta, Ed.). Bandung.

Sugiyono. (2014). Metodologi Penelitian Kuantitatif Kualitatif dan R\&D. Bandung: Alphabeta.

Sugiyono. (2017). Metode Penelitian Bisnis. Bandung: CV Alfabeta.

Sukma Yoli Lara. (2013). Pengaruh Dana Pihak Ketiga, Kecukupan Modal Dan Risiko Kredit Terhadap Profitabilitas (Perusahaan Perbankan yang Terdaftar 
di BEI. Jurnal Akuntansi, 1 (2).

Syamsu Iskandar. (2013). Bank dan Lembaga Keuangan Lainnya. (IN MEDIA, Ed.). Jakarta.

Syarif Syahru. (2006). Analisis Pengaruh Rasio-Rasio CAMELS Pada Net Interest Margin (Study Empiris Pada Bank-bank yang Listed di Bursa Efek Jakarta Periode Tahun 2001-2004).

Taswan. (2008). Manajemen Perbankan: Konsep, Teknik dan Aplikasi. Yogyakarta: UPP STIM YKPN Yogyakarta.

Uremadu, S. O. (2012). Bank Capital Structure , Liquidity and Profitability Evidence from the Nigerian Banking System 1, 3(1), 98-113.

Warsa MI, M. I. (2016). Pengaruh CAR, LDR dan NPL Terhadap ROA Pada Sektor Perbankan di Bursa Efek Indonesia. E-Jurnal Manajemen Universitas Udayana, 5(5).

Wiagustini, N. L. P. (2013). Manajemen Keuangan. Denpasar: Udayana University Press.

Wibisono, K. (2014). Analisis Pengaruh Car, Npl, Nim, Dan Ldr Terhadap Roa Pada Bank Umum Swasta Nasional Di Indonesia. Jurnal Ekonomi Daerah (JEDA), 1(1).

Zakaria. (2015). The link between ownership structure, Loan to Deposit Ratio, Nonperforming Loan and Return on Equity: evidence from the Indonesian banking industry. International Journal of Humanities and Social Science Invention ISSN (Online, 4(5), 2319-7722. https://doi.org/DOI 10.1007/s10522-004-7379-6 